\title{
Caudal Dysplasia
}

National Cancer Institute

\section{Source}

National Cancer Institute. Caudal Dysplasia. NCI Thesaurus. Code C124505.

A cong enital abnormality characterized by the abnormal development of the lower portion of the body. Findings include hypoplastic lower extremities, defects of the caudal vertebrae, sacrum and neural tube, or maldeveloped gastrointestinal or genital organs. 